\title{
Virus-like particles associated with brown muscle disease in Manila clam, Ruditapes philippinarum, in Arcachon Bay (France)
}

\author{
C Dang ${ }^{1,{ }^{*}}$, P Gonzalez ${ }^{1}$, N Mesmer-Dudons ${ }^{1}$, J-R Bonami $^{2}$, N Caill-Milly $^{3}$ and X de Montaudouin ${ }^{1}$
}

${ }^{1}$ Université Bordeaux 1, CNRS, EPOC, UMR 5805, Station Marine d'Arcachon, Arcachon, France

${ }^{2}$ Pathogens and Immunity, UMR 5119, ECOLAG, CNRS/UM2, Université Montpellier, Montpellier, France

${ }^{3}$ Laboratoire Ressources Halieutiques Aquitaine, IFREMER, 1 allée du Parc Montaury, Anglet, France

*: Corresponding author : C. Dang, Tel: + 335562239 36, Fax: + 335568351 04, email address :

c.dang@epoc.u-bordeaux1.fr

\begin{abstract}
:
Recently, Manila clam, Ruditapes philippinarum, populations have suffered mortalities in Arcachon Bay (SW France). Mortality was associated with extensive lesions of the posterior adductor muscle, which become progressively brown and calcified. Ultrastructural observations by transmission electron microscopy revealed tissue degradation with necrotized muscle fibres and granulocytomas. Unenveloped virus-like particles (VLPS) were detected in muscle, granulocytic, epithelial and rectal cells. VLPs were abundant in the extracellular space, in the cytoplasm (free or enclosed in vesicles) and in the nucleoplasm of granulocytes. Nuclei and mitochondria of granulocytes displayed changes which suggested reactive oxygen species production and apoptosis induction. VLPs exhibited an icosahedral structure with a diameter of 25 to $35 \mathrm{~nm}$. These observations suggest that the VLPs could belong to the family Picornaviridae or the Parvoviridae.
\end{abstract}

Keywords: adductor muscle $\bullet$ apoptosis $\bullet$ brown muscle disease $\bullet$ necrosis $\bullet$ Ruditapes philippinarum - transmission electron microscopy 


\section{Introduction}

The Manila clam Ruditapes philippinarum is one of the most exploited bivalve mollusks in the world. This species has a relatively high commercial value in France. In 2006, Arcachon Bay (Southwest France) ranked first among commercial species in France in standing stock $(7600 \mathrm{t})$ and production (450 mt). Normally, the Manila clam is an infaunal bivalve living a few centimeters under the sediment surface. Recently, in large areas within the bay, a significant quantity of individuals was retrieved from the sediment surface. They were often gaping or were recently dead. Mortality was associated with lesions of the posterior adductor muscle that became progressively brown and calcified. This pathology has been named Brown Muscle Disease (BMD) and etiologic agents have been sought (Dang, de Montaudouin, Gonzalez, Mesmer-Dudons \& Caill-Milly 2008). Light microscopy has not revealed any causal agent. Bacteria and protozoan agents being excluded, a viral etiology has been hypothesized.

The first report of viruses in bivalve mollusks was a herpes-like virus in oyster tissues (Farley, Banfield, Kasnic \& Foster 1972). Many reports of different virus families were subsequently described in several mollusk species around the world (Comps, Bonami \& Vago 1976, Comps \& Duthoit 1976, Johnson 1984). Mortalities associated with viruses have been observed in many bivalve species in different parts of the world. For instance, mortalities occurred in Crassostrea angulata from 1970 to 1973 along French Atlantic coast as a consequence of an iridovirus (Comps et al. 1976, Comps \& Duthoit 1976) and in Crassostrea gigas in 1977 due to a similar iridovirus (Comps \& Bonami 1977). Mass mortality of the pearl oyster Pinctada margaritifira was recorded in 1985 with associated necrosis of the adductor muscle. Virus-like particles of $40 \mathrm{~nm}$ in diameter were detected (Comps, Herbaut \& Fougerouse 1999, Comps, Herbaut, Fougerouse \& Laporte 2001). Other severe mortality events were reported in bivalve populations in relation with the presence of virus-like particles (Miyazaki, Goto, Kobayashi, Kageyama \& Miyata 1999, Novoa \& Figueras 2000, Johnson 1984, Jones, Scotti, Dearing \& Wesney 1996, Hine \& Wesney 1997).

This paper reports the first morphological and ultrastructural description of virus-like particles associated with the Manila clam Brown Muscle Disease, as well as the histological changes observed in the bivalve infected tissues.

\section{Materials and methods}

Specimens of Ruditapes philippinarum were collected from an intertidal site in Arcachon Bay. Manila clams were selected for the study in the three pathological stages previously described (Dang et al, 2008): healthy $(n=5)$, intermediate $(n=10)$ and advanced stages $(n=$ 10). Clams were opened by sectioning the adductor muscle with a scalpel blade and striated muscles were dissected and therefore fixed for histological examination. The muscle was fixed in $2.5 \%$ glutaraldehyde buffered with $0.1 \mathrm{mmol} \mathrm{L}^{-1}$ sodium cacodylate solution and synthetic seawater for $12 \mathrm{~h}$ at $4{ }^{\circ} \mathrm{C}$, rinsed in a cacodylate buffer $\left(0.1 \mathrm{mmol} \mathrm{L}^{-1}, \mathrm{NaCl} 2 \%\right)$, postfixed in $1 \% \mathrm{OsO}_{4}$ for $2 \mathrm{~h}$, dehydrated through a graded series of ethanol (50 to $100 \%$ ), and embedded in araldite. Ultrathin sections (500 - $700 \AA$ ) were cut and examined without staining on a Philips Tecnai 12 transmission electronic microscope.

In order to observe the attachment zone of the muscle and palleal epithelium cells, muscles and shells from two uninfected and six diseased clams were decalcified. The shell and the muscle were decalcified in EDTA $7 \%$ for 18 days. EDTA solution was changed every day until complete decalcification. Then, treatment of samples was executed as previously mentioned. 


\section{Results}

All infected clams in intermediate and ultimate stages of the disease exhibited electrondense particles of 25 to $35 \mathrm{~nm}$ widespread in tissues, in contrast to healthy clams in which no virus-like particles (VLPs) were detected.

Histological section of clams observed in transmission electron microscopy (TEM) showed in healthy specimens a classical muscle arrangement, with muscular fibers composed of several myofibrils (Fig. 1a). However, diseased clams exhibited an extensive necrosis and a complete muscular disorganization (Fig. 1b, c, d, e, f).

During the study of the clams showing intermediary stage of BMD infestation, two different situations were observed under TEM: the first with remnants of muscular fibers and few granulocytes (Fig. 1b, c, d); the second with an extensive granulocytomas as this has been previously described in light microscopy (Dang et al. 2008) (Fig. 1e, f). In both situations, the tissue was seriously disrupted.

In clams showing first intermediate stage of BMD disease, muscular fibers were completely necrotized, atrophied, and without a normal muscle bundle organization (Fig. 1b). At this stage, muscle cells were not discernible. Only remnants of deteriorated fibers without any adhesion were observed. These degraded muscle fibers were interspersed with hemocytes and particularly granulocytes (Fig. 1b). This is the first line of cellular defense in bivalves. Inside sarcoplasms, vesicles containing electron dense VLPS could be noticed (Fig. 1c). VLPs could be found either in vacuoles inside fibers (Fig. 1c) or near damaged fibers (Fig. 1d) perhaps in sarcoplasm. The tissue was so degraded that it was not possible to determine the intra- or extracellular position of VLPS, but observations suggested that they were present in both locations.

Secondly, significant hemocyte infiltration was observed (Fig. 1e). These hemocytes contained in their cytoplasm numerous dark granules and were identified as granulocytes. They may have digested muscle cell debris. Granulocytomas seemed to be a stage more advanced than the first intermediate stage previously described with remnants of muscular cells.

VLP-associated granulocytomas were observed (Fig. 1f). Like in muscle cells, VLPs could either have extracellular (Fig. 1f) or intracellular locations (Fig. 2a, d, e). Indeed, VLPs could be found in vesicles inside the cytoplasm of the granulocyte (Fig. 2a).

The nucleus of granulocytes appeared abnormal with a prominent lateral displacement of the nucleoli (Fig. 2b) which may be the sign of replication and a slightly higher degree of chromatin condensation. Inclusion bodies were absent. At a higher level of infection, nuclei appeared pycnotic and condensed (Fig. 2c, d). Within the nucleoplasm, VLPs were observed and had the same structure and size as other VLPs (Fig. 2d, e). In these figures, the nucleus was pycnotic; the heterochromatin almost occupied the totality of the nucleus. However, VLPs were less electron-dense than compared to the extracellular or cytoplasmic virions and its appearance remembered viruses in process of assembly.

Furthermore, granulocytes possessed abnormal mitochondria with loss or disorganization of cristae architecture (Fig. 2f). These organelles appeared empty with only short or fragmented cristae.

Decalcification of our samples permitted the observation of epithelial cells, responsible for shell secretion and the observation of the attachment zone of muscular cells (Fig. 3a). VLPS were detected in the cytoplasm of these cells within endocytotic vesicles (Fig. 3b, c). VLPs were also detected in the cytoplasm of rectal cells, which are adjacent to muscle cells (Fig. $3 d$, e). They had invaded the rough endoplasmic reticulum (Fig. 3d, e). In Fig. 3d, the internal and external membranes of the nucleus seemed irregular and dissociated. Blisters appeared between both nuclear membranes.

In the advanced stage, tissue was so disrupted that no structure was recognizable. Remnants of lysed cells as membranes and degradation bodies were present. Large amounts of VLPS were observed in this stage. They could be densely enclosed in vesicles, or free throughout cellular debris (Fig. 3f). Paracrystalline arrays occurred frequently in this 
ultimate stage of brown muscle disease (Fig. 4a). VLPs were non-enveloped and measured from 25 to $35 \mathrm{~nm}$ in diameter (Fig. 4b). They appeared icosahedral in shape and exhibited an homogenously electron dense center (Fig. 4b).

\section{Discussion}

In the literature, only one virus is known to infect and replicate in $R$. philippinarum tissues, a herpes-like virus which infects larvae. It induced sporadic mortalities in French hatcheries in 1997 (Renault, Lipart \& Arzul 2001b, Renault, Lipart \& Arzul 2001a). No virus has been described in adult Manila clams. However, virus-like particles (VLPS) have been found in $R$. decussatus in Spain (Novoa \& Figueras 2000).

Similar symptoms and associated virus particles were reported in the scallop Patinopecten yessoensis (Mori 1975), in the Japanese pearl oyster Pinctada fucata martensii (Miyazaki et al. 1999) and in the Polynesian pearl oyster Pinctada margaritifira (Comps et al. 1999, Comps et al. 2001). Like BMD, both oyster diseases displayed an extensive necrosis and atrophy of the muscle fibers with a prominent inflammatory response and mass mortality of oysters. In the altered muscle tissues of the Japanese pearl oyster, inclusion bodies contained virions from 25 to $33 \mathrm{~nm}$ in size, presumably containing a RNA genome (Miyazaki et al. 1999). On other hand, $40 \mathrm{~nm}$ VLPs were reported from the granulocytomas tissue of the Polynesian pearl oyster (Comps et al. 1999).

In the Japanese pearl oyster, the pathology is combined with a yellowish to brown coloration of the adductor muscle but the disease also affects pallial, foot, gill and cardiac musculature. Although other musculatures are not considered here, it doesn't seem that other tissues than the adductor muscle are infected based on gross observation.

Clams affected by BMD showed highly degenerated muscle fibers. The tissue was so destroyed that the disease could be detected through gross observation. The gradation of coloration (from yellowish to brown) corresponds with infection intensity. A contrast with the Miyazaki et al (1999) report is the calcification of infected Manila clam adductor muscle. At each level of infection, VLPs were observed in different cellular types: muscular, epithelial, granulocytic and rectal as well as in different locations, intranuclear, cytoplasmic and extracellular.

The observation of VLPS in cells was dependent on cell type. VLPs were exclusively observed into endocytotic vesicles in epithelial cells, and free in the cytoplasm of rectal cells which might suggest a direct penetration. In these rectal cells, they were found in association with the rough reticulum. We also emphasize the resemblance with the virus-like particles found in mussel Perna canaliculus (Jones et al. 1996) and in scallop Pecten novaezelandiae (Hine 1997). In muscle cells, VLPs were observed inside vesicles and free in the sarcoplasm at a higher degree of infection. An important necrosis phenomenon takes place in the muscle. Miyazaki (1999) reported in the Japanese pearl oyster the formation of membranous inclusion bodies in the sarcoplasm of necrotized muscular fibers which contained viral particles.

The presence of pathological granulocytes forming granulocytomas was considerable in muscle tissues like in Pinctada fucata martensii (Miyazaki et al. 1999), in Pinctada margaritifira (Comps et al. 1999) and in Mytilus edulis (Rasmussen 1986). The lesions found in Ruditapes philippinarum displayed some similarities to granulocytomas which developed in the mussel Mytilus edulis infected by a picornavirus (Rasmussen 1986). This virus replicated in cytoplasmic vesicles within granulocytes which could aggregate to form the granulocytomas. For the moment the first cellular type colonized by VLPs is unknown even if it should be logical that infection begins by muscular cells. Afterwards, granulocytes might be arriving to phagocytose infected muscle cells and they become subsequently infected. It is also possible that VLPs pass from muscle cells to adjacent rectal cells. These last points are hypothetical. 
Nuclei of granulocytes and rectal cells presented lethal alterations like heterochromatin margination, lateral displacement of the nucleus and dilatation of the nuclear cisternae (blisters). Features indicated the imminent pycnosis and consequently the death of cells (Cabanne \& Bonenfant 1986). Some of these alterations argue for apoptosis signs (programmed cell death) like aggregation of condensed chromatin along the inner nuclear membrane and global signs of nucleus collapse (Desprès, Flammand, Ceccaldi \& Deubel 1996, Wattre 1999). Viral protein may be responsible for apoptosis either during particle penetration or during the release of structural protein into the cell (Desprès et al. 1996, Hanon, Vanderplasschen, Lyaku, Keil, Denis \& Pastoret 1996). In some pycnotic nuclei, high concentration of VLPs was observed, which argues for virus multiplication in the nucleus and consequently a possible DNA-based viral genome. In this case, VLPs were less electrondense, which suggests an early stage of assembly.

In granulocytes, the analysis of mitochondrial ultrastructure showed the occurrence of cristae loss and disorganization. The same phenomenon of destroyed cristae was reported in Pinctada fucata martensii muscle fibers (Miyazaki et al. 1999). It could be hypothesized that damaged mitochondria and such cristae disorganization could reflect the occurrence of an apoptotic event in this organelle. In this context, recent reports suggested that some viruses are able to induce reactive oxygen species (ROS)-mediated cell apoptosis (Wang \& Weinman 2006, Schmitt \& Reiter 2008). Activated granulocytes certainly play an important role in virus infections and their destruction can delay viral clearance, facilitating the spread of viruses in the host. The induction of apoptosis provides a means for the virus to establish a balanced long-term relationship with the host immune system, sacrificing other cells to undergo infection and there by promoting viral survival (Renault et al. 2001b, Desprès et al. 1996, Miller \& White 1998, Wattre 1999).

Studies on viral agents in mollusks are limited by the lack of molluskan cell-lines to cultivate the putative viruses. Consequently, determination of virus family is mostly carried out by TEM approaches. Due to morphological criteria, VLPs of the brown muscle disease could belong either to the Picornaviridae (Moore \& Eley 1991, Rueckert 1971, Godman 1973) or Parvoviridae (Tijssen \& Arella 1991, Mayor 1973). The VLP was non-enveloped, and the capsid was apparently icosahedral and measured approximately 25 to $35 \mathrm{~nm}$ in diameter. Picornaviridae have single-stranded RNA and Parvoviridae single-stranded DNA genomes. R. philippinarum VLPs present high similarities in size, structure and cellular position to the Bay of Piran Shrimp Virus (BPSV) (Vogt 1996). BPS virions are spherical to angular, nonenveloped and measure around 22 to $27 \mathrm{~nm}$ in sections. Like the present VLPS, BPSV could be found either in extracellular position, accumulated in the cytoplasm but also abundant within membrane whorls, in association with the rough endoplasmic reticulum or within the nucleoplasm, depending of the cell type. BPSV has been described to probably belong to the Picornaviridae or to the Parvoviridae.

At first glance, Manila clam VLP seems to be a picornavirus, since it is located in the cytoplasm like the virus found by Miyazaki (1999) in the Japanese pearl oyster. Viruses related to the Picornaviridae are host-species specific. The extensive cellular damage and incomplete maturation of the VLP found by electronic microscopy are in agreement with observations related to picornavirus infection in other animal species (Godman 1973).

However, the putative assemblage of the VLP within the nucleus would argue for the Parvoviridae. Furthermore, a similar cytoplasmic virus, the IHHNV (infectious hypodermal and hematopoietic virus) of penaeid shrimps previously assumed to be a Picornaviridae has meanwhile been assigned to the Parvoviridae by molecular analysis (Mari, Bonami \& Lightner 1993).

On the basis of our investigation, the high infection rate, behavioral changes and gross pathological symptoms in the infected clams, and the presence of immune defense reactions suggest a severely pathogenic infection. However, further attempts to isolate the virus are required to confirm the role of these virus-like particles as the cause of brown muscle disease and to realize transmission tests on healthy animals. Molecular analysis (sequencing) will be necessary to relate this virus to a family. 


\section{Acknowledgements}

Authors are particularly grateful to P. Lebleu, F. Prince, F. Huchin and M. Basterretxea for their assistance in the field and R. B. Carnegie for English editing. C. Dang was supported by a grant from Fonds Communs de Coopération Aquitaine-Euskadi and Conseil Général de la Gironde. This study was partly financed by the project «Multistress » from the French Research National Agency (ANR) coordinated by X. de Montaudouin.

\section{Literature cited}

Cabanne F. \& Bonenfant J.L. (1986) Anatomie pathologique : principes de pathologie spéciale et d'aetopathologie, Les Presses de l'université Laval du Québec, Maloine Éditeur, Paris

Comps M. \& Bonami J.-R. (1977) Infection virale associée à des mortalités chez l'huître Crassostrea gigas. Comptes Rendus de l'Academie des Sciences. Paris, 285, 1139-1140.

Comps M., Bonami J.-R. \& Vago C. (1976) Une virose de l'huître portugaise (Crassostrea angulata LMK). Comptes Rendus de l'Academie des Sciences. Paris, t 282, 139-142.

Comps M. \& Duthoit J.L. (1976) Infection virale associée à la "maladie des branchies" de l'huître portugaise Crassostrea angulata. Comptes Rendus de l'Academie des Sciences. Paris, 283, 1595-1598.

Comps M., Herbaut C. \& Fougerouse A. (1999) Virus-like particles in pearl oyster Pinctada margaritifera. Bulletin of the European Association of Fish Pathologists, 19, 85-88.

Comps M., Herbaut C., Fougerouse A. \& Laporte F. (2001) Progress in pathological characterization of Syndrome 85 in the black-lip pearl oyster Pinctada margaritifera. Aquatic Living Resources, 14, 195-202.

Dang C., De Montaudouin X., Gonzalez P., Mesmer-Dudons N. \& Caill-Milly N. (2008) Brown Muscle Disease (BMD), an emergent pathology affecting Manila clam Ruditapes philippinarum in Arcachon Bay (SW France). Diseases of Aquatic Organisms, 80, 219-228.

Desprès P., Flammand M., Ceccaldi P.E. \& Deubel V. (1996) Human isolates of Dengue type 1 virus induce apoptosis in mouse neuroblastoma cells. Journal of Virology, 70, 4090-4096.

Farley C.A., Banfield W.G., Kasnic G. \& Foster W.S. (1972) Oyster herpes-type virus. Science, 178, 759-760.

Godman G.C. (1973) Picornaviruses. In: Ultrastructure of animal viruses and bacteriophages (ed. by A.J.D.A.F. Haguenau), pp. 133-153. Academic Press, New York and London.

Hanon E., Vanderplasschen A., Lyaku J., Keil G., Denis M. \& Pastoret P.P. (1996) Inactivated bovine herpesvirus 1 induces apoptotic cell death of mitogen-stimulated bovine peripheral blood mononuclear cells. Journal of Virology, 70, 4116-4120.

Hine P.M. (1997) Virus-like particles associated with cytopathology in the digestive gland epithelium of scallops Pecten novaezelandiae and toheroa Paphies ventricosum. Diseases of Aquatic Organisms, 29, 197-204.

Hine P.M. \& Wesney B. (1997) Virus-like particles associated with cytopathology in the digestive gland epithelium of scallops Pecten novaezelandiae and tohera Paphies ventricosum. Diseases of Aquatic Organisms, 29.

Johnson P.T. (1984) Viral disease of marine invertebrate. Diseases of Aquatic Organisms, 37, 65-98.

Jones J.B., Scotti P.D., Dearing S.C. \& Wesney B. (1996) Virus-like particles associated with marine mussel mortalities in New Zealand. Diseases of Aquatic Organisms, 25, 143-149.

Mari J., Bonami J.R. \& Lightner D. (1993) Partial clonong of the genome of infectious hypodermal and hematopoietic necrosis virus, an unusual parvovirus pathogenic for penaeid shrimps; diagnosis of the disease using a specific probe. Journal of General Virology, 74, 2637-2643. 
Mayor H.D. (1973) Picodnaviruses. In: Ultrastructure of animal viruses and bacteriophages (ed. by A.J.D.A.F. Haguenau), pp. 23-45. Academic Press, New York and London.

Meyers T.R. (1984) Marine bivalve mollusks as reservoirs of viral finfish pathogens: significance to marine and anadromous finfish aquaculture. Marine Fisheries Review, 46, 1417.

Miller L.K. \& White E. (1998) Apoptosis in virus infection. Seminar in virology, 8, 443-444.

Miyazaki T., Goto K., Kobayashi T., Kageyama T. \& Miyata M. (1999) Mass mortalities associated with a virus disease in Japanese pearl oyster Pinctada fucata martensii. Diseases of Aquatic Organisms, 37, 1-12.

Moore N.F. \& Eley S.M. (1991) Picornaviridae: Picornaviruses of invertebrates. In: "Atlas of Invertebrate Viruses" (J. R. Adams and J. R. Bonami, Eds) (ed. by B.R. Crc Press), pp. 371386.

Mori K. (1975) Seasonal variation in physiological activity of scallops, under culture in the coastal waters of Sanriku distrivt, Japan, and a physiological approach of a possible cause of their mass mortality. Bulletin of the Marine Biological Station of Asamushi, 15, 59-79.

Novoa B. \& Figueras A. (2000) Virus-like particles associated with mortalities of the carpetshell clam Ruditapes decussatus. Diseases of Aquatic Organisms, 39, 147-149.

Pang Z.C., Sun K.C. \& Zhang A.H. (1995) Study on contamination of Ruditapes philippinarum by HAV in Jiaozhou Bay and its counter-measures. Zhonghua liu xing bing xue za zhi, 16, 137-139.

Rasmussen L.P.D. (1986) Virus-associated granulocytomas in the marine mussel, Mytilus edulis, from three sites in Denmark. Journal of Invertebrate Pathology, 48, 117-123.

Renault T., Lipart C. \& Arzul I. (2001a) A herpes-like virus infecting Crassostrea gigas and Ruditapes philippinarum larvae in France. Journal of Fish Diseases, 24, 369-376.

Renault T., Lipart C. \& Arzul I. (2001b) A herpes-like virus infects a non-ostreid bivalve species: virus replication in Ruditapes philippinarum. Diseases of Aquatic Organisms, 45, 17.

Rueckert R.R. (1971) Picornaviral architecture. In: Comparative Virology (K. Maramorosh and E. Kurstak, eds.) (ed. by N.-Y. Academic Press), pp. 256-300.

Schmitt M.J. \& Reiter J. (2008) Viral induced yeast apoptosis. Biochimica et Biophysica acta. Tijssen P. \& Arella M. (1991) Parvoviridae. Structure and reproduction of densonucleosis viruses. In: "Atlas of Invertebrate Viruses" (ed. by E. J. R. Adams and J. R. Bonami), pp. 4153. CRC Press, Boca Raton.

Vogt G. (1996) Cytopathology of bay of Piran shrimp virus (BPSV), a new crustacean virus from the mediterranean sea. Journal of Invertebrate Pathology, 68, 239-245.

Wang T. \& Weinman S.A. (2006) Causes and consequences of mitochondrial reactive oxygen species generation in hepatitis C. Journal of Gastroenterology \& Hepatology, 21: S34-37., S34-37.

Wattre P. (1999) Apoptose et virus (hormis les rétrovirus). Revue Francaise des Laboratoires, 311, 43-49.

\section{Figures}

Fig. 1. Ultrathin sections of Ruditapes philippinarum muscle observed under transmission electron microscopy (TEM). (a) Adductor muscle transversal cut of healthy Manila clam (scale bar, $5 \mu \mathrm{m}$ ). (b - f) Adductor muscle of brown muscle disease intermediate stage. (b) Degraded fibers (DF) interspaced by granulocytes (G) (scale bar, $2 \mu \mathrm{m}$ ). (c) Virus-like particles (VLPS) (arrows) within vesicles (V) in degraded muscle fiber (scale bar, $2 \mu \mathrm{m}$ ). (d) Fiber in degradation (DF) with VLPs (arrows) in sarcoplasm (scale bar, $1 \mu \mathrm{m}$ ). (e) Intense granulocytes $(G)$ infiltration (granulocytomas) within the muscle (scale bar, $5 \mu \mathrm{m}$ ). (f) Extracellular VLPS (arrows) in a granulocytes infiltration. Granulocytes (G) contained many dark granules $(\mathrm{g})$ (scale bar, $1 \mu \mathrm{m})$. 
Fig. 1.

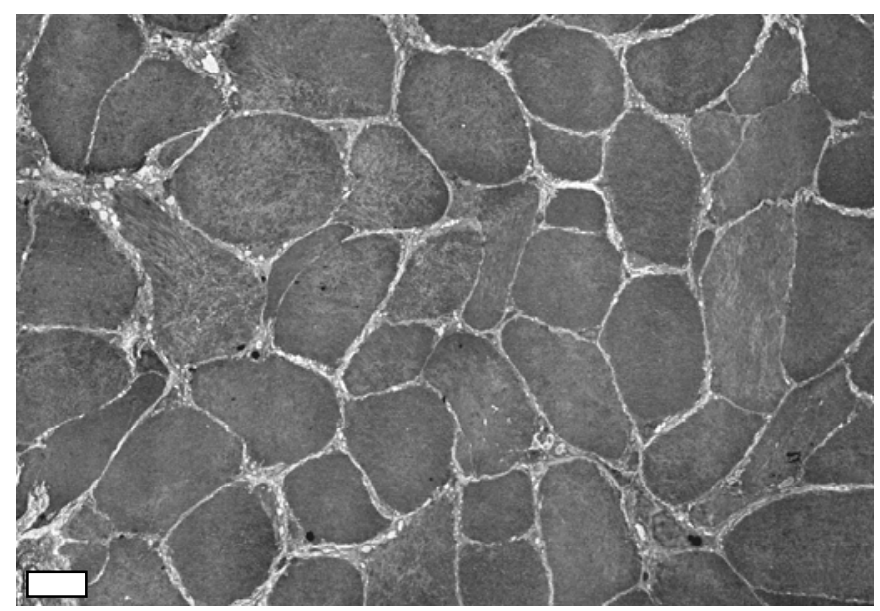

(a)

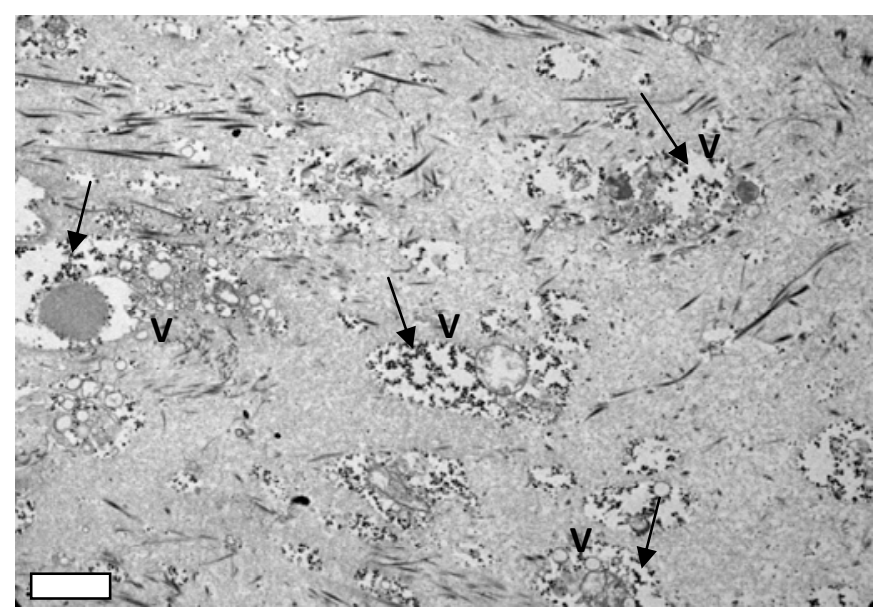

(c)

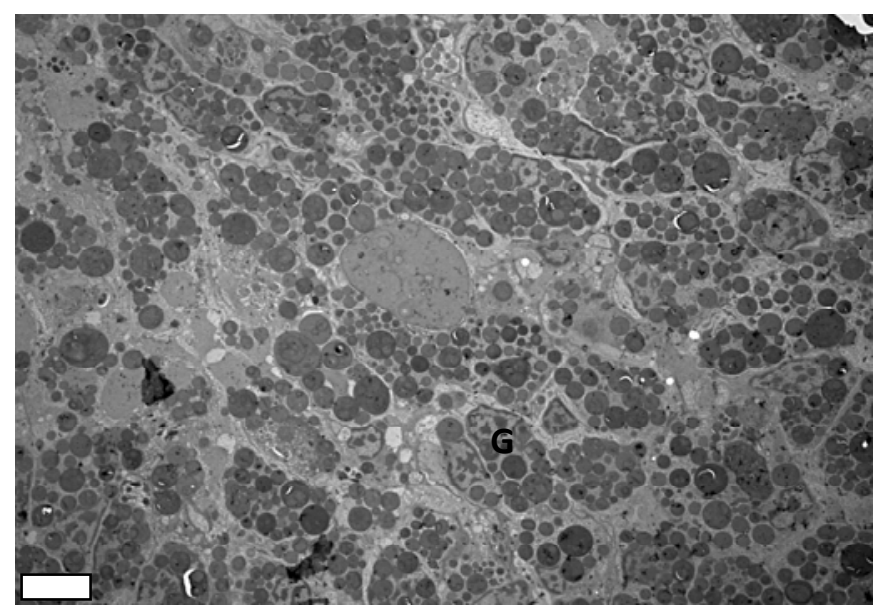

(e)

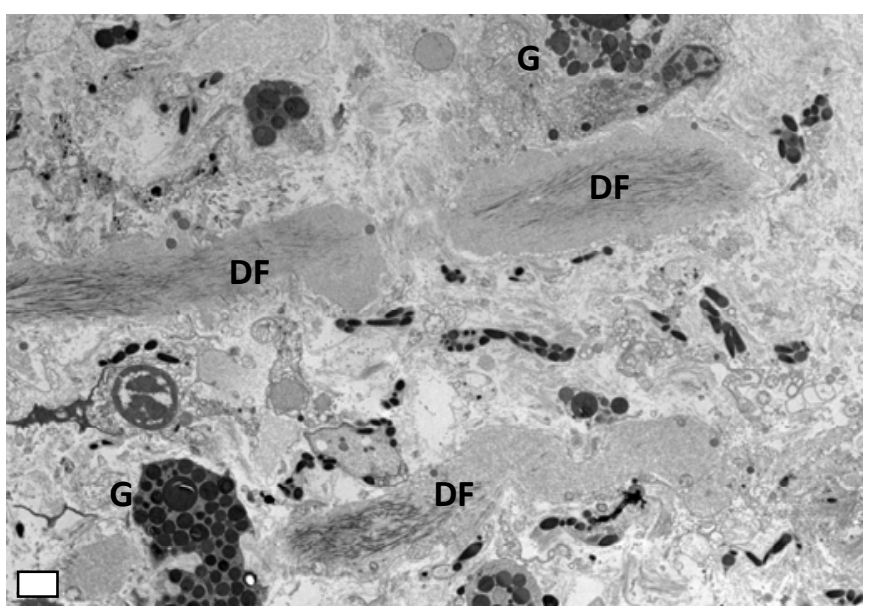

(b)

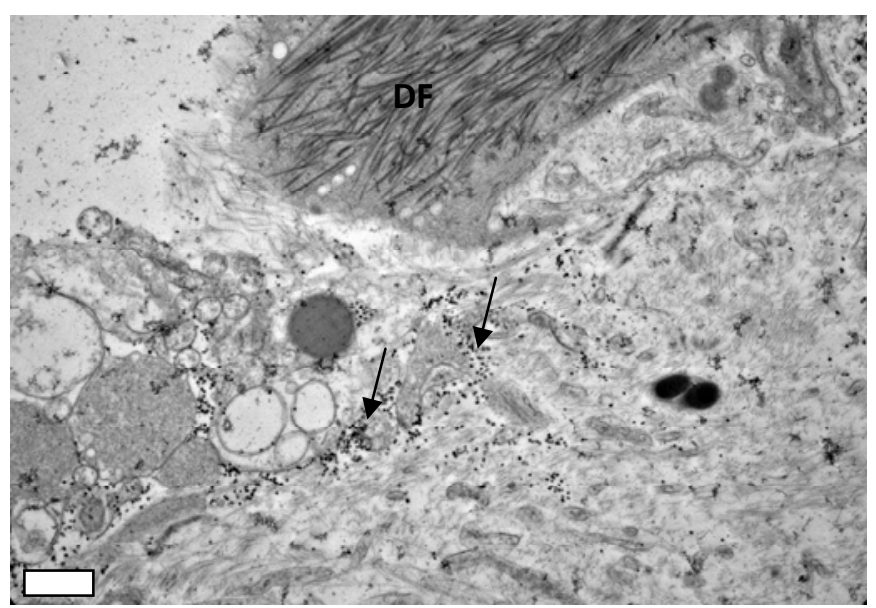

(d)

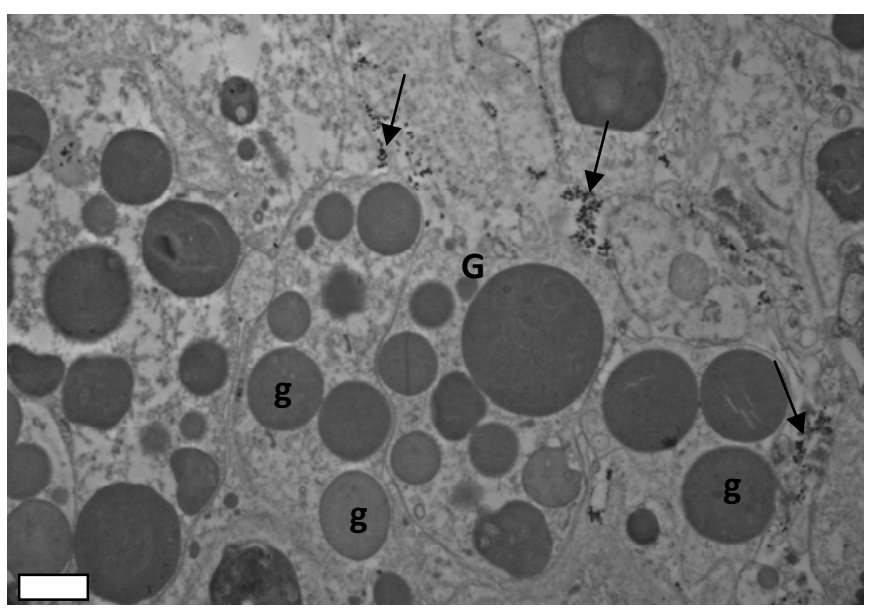

(f) 
Fig. 2. Ultrathin sections of granulocytes of $R$. philippinarum muscle infected by BMD intermediary stage in TEM. (a) VLPs (arrows) within vesicles (V) in the cytoplasm. HC, heterochromatin (scale bar, $200 \mathrm{~nm}$ ). (b) Nucleus (N) of a granulocyte with laterally displaced nucleolus $(\mathrm{Nu})$ and prominent heterochromatin clumps (HC). g, granule (scale bar, $200 \mathrm{~nm}$ ). (c) Nuclei $(\mathrm{N})$ of granulocytes with condensed heterochromatin (HC). g, granule (scale bar, 1 $\mu \mathrm{m})$. (d) Virus-like particles (arrows) in nucleoplasm of infected granulocyte. N, nucleus (scale bar, $500 \mathrm{~nm}$ ). (e) Close up of VLPs in nucleoplasm (scale bar, $200 \mathrm{~nm}$ ). (f) Mitochondria (M) of infected granulocyte with loss of the cristae architecture. g, granule (scale bar, $200 \mathrm{~nm}$ ). 
Fig.2.

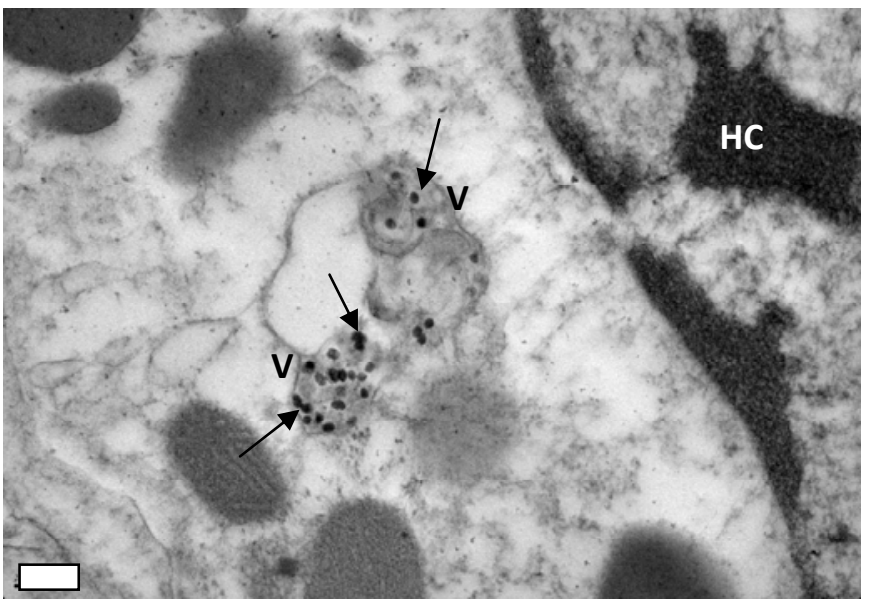

(a)

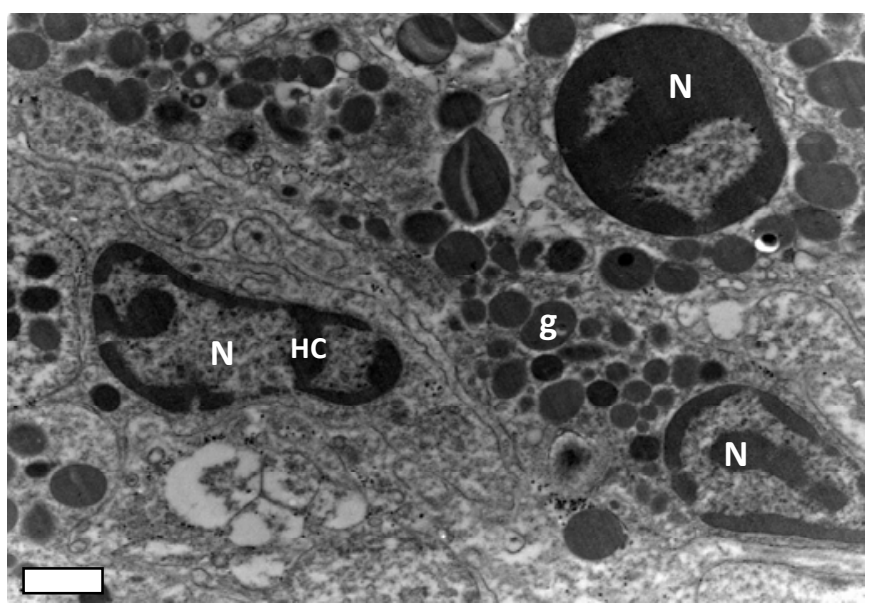

(c)

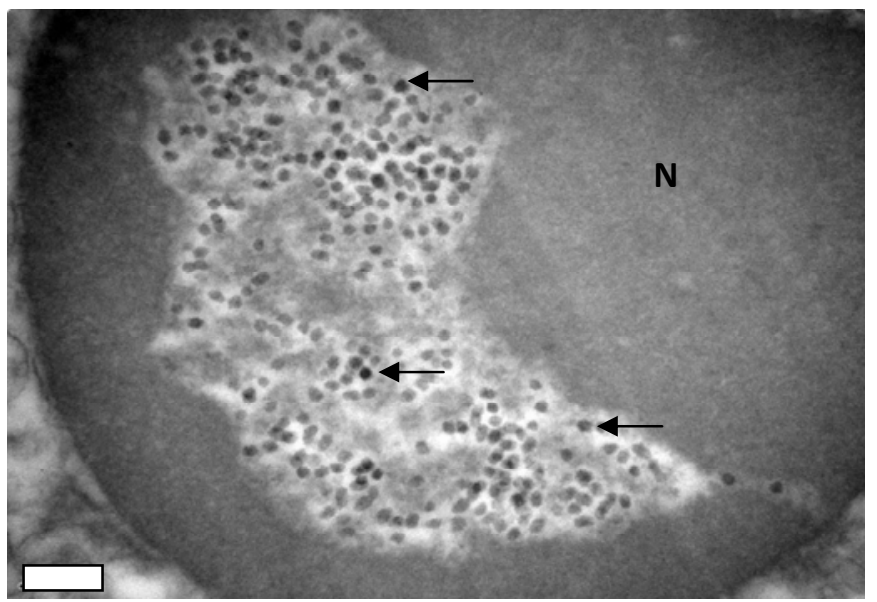

(e)

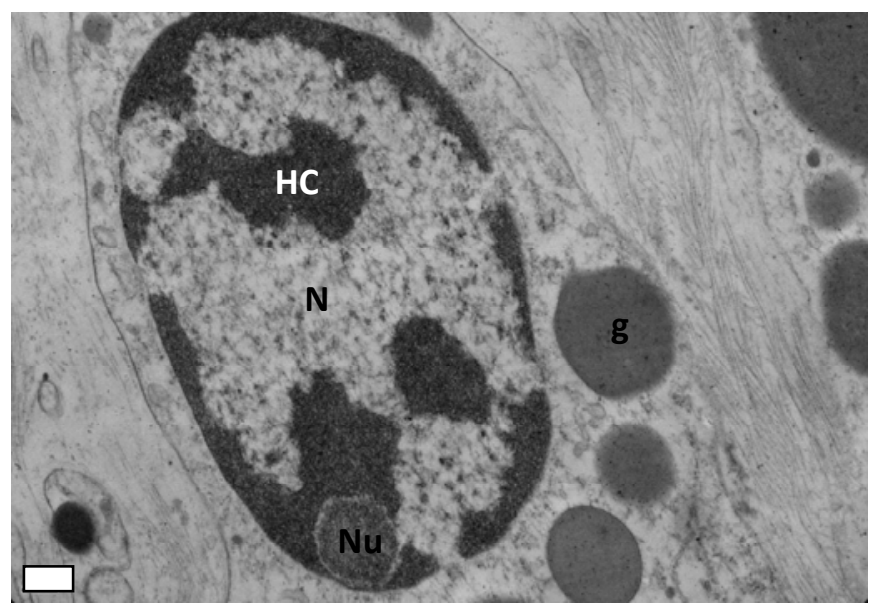

(b)

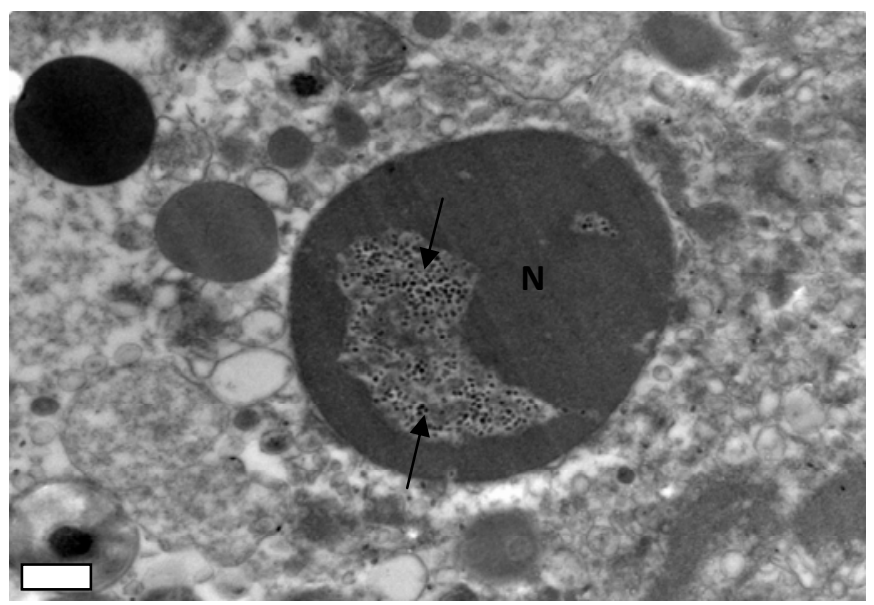

(d)

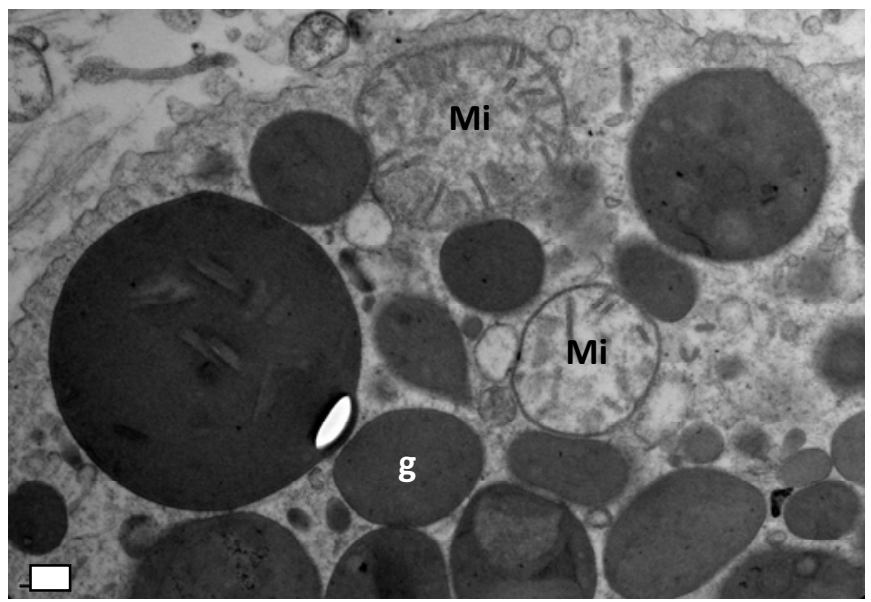

(f) 
Fig. 3. Intermediate stage of BMD in $R$. philippinarum tissues observed under TEM. (a) Attachment zone of muscle cells with muscle fiber (MF) and epithelial cells (EC) (scale bar, 1 $\mu \mathrm{m}) .(\mathbf{b}-\mathbf{c})$ VLPS (arrows) within vesicles (V) in the cytoplasm of epithelial cells (EC). Mv, microvillosity. N, nucleus. HC, heterochromatin (scale bar, $200 \mathrm{~nm}$ ). (d) VLPs (arrows) in cytoplasm of rectal cell. Internal and external nuclear membranes were dissociated and presented blisters (dotted arrows). N, nucleus. HC, heterochromatin. rER, rough endoplasmic reticulum (scale bar, $1 \mu \mathrm{m}$ ). (e) VLPs (arrows) in cytoplasm of rectal cells (scale bar, $1 \mu \mathrm{m}$ ). (f) Advanced stage of BMD. VLPs (arrows) within vesicles (V) or free among cellular debris (scale bar, $200 \mathrm{~nm}$ ). 
Fig. 3.

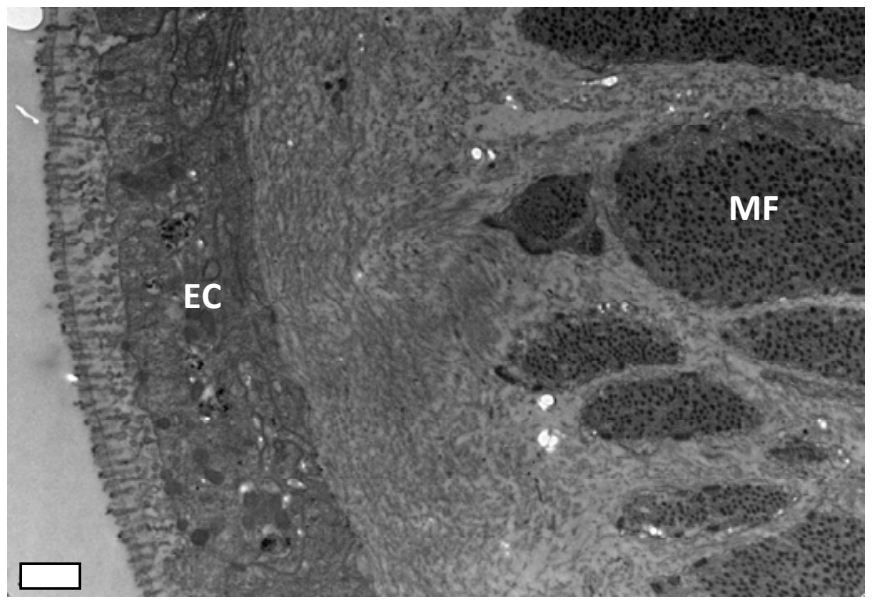

(a)

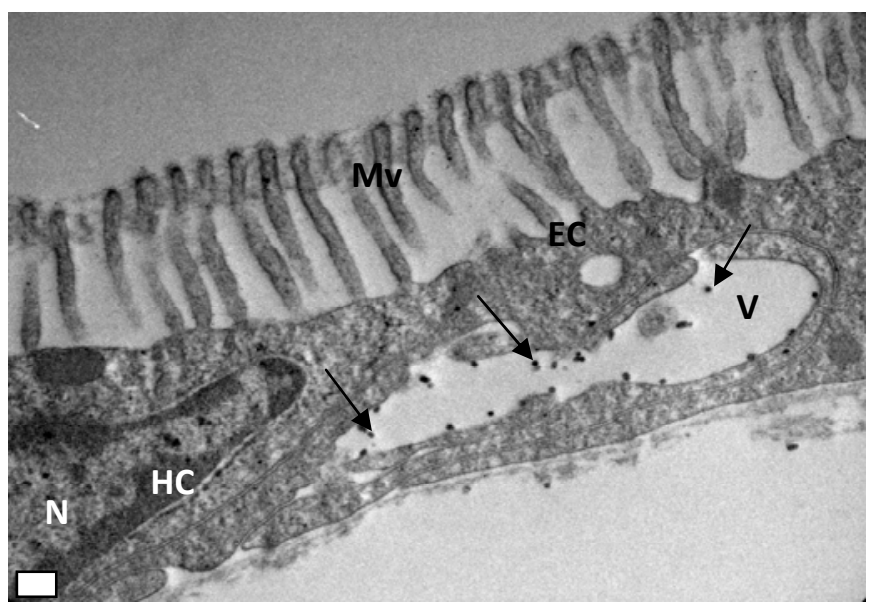

(c)

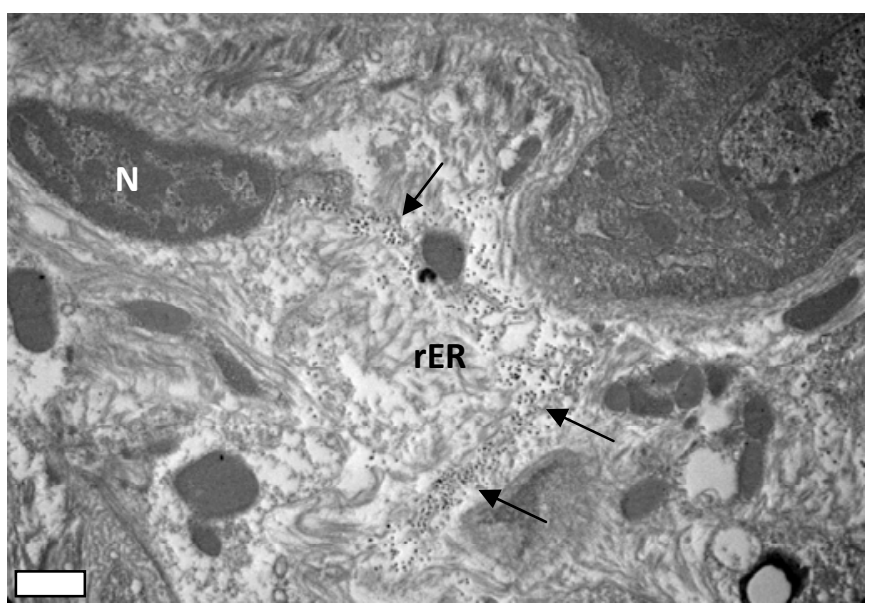

(e)

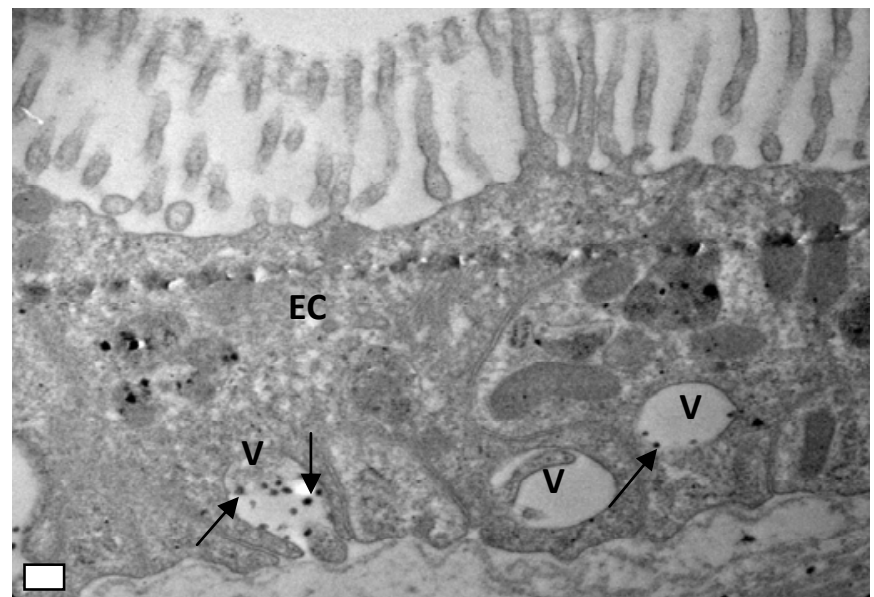

(b)

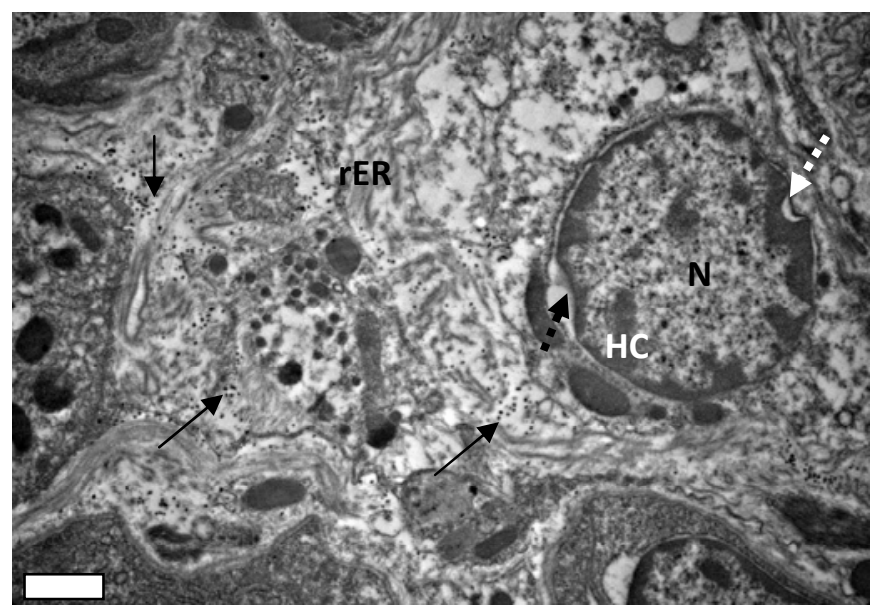

(d)

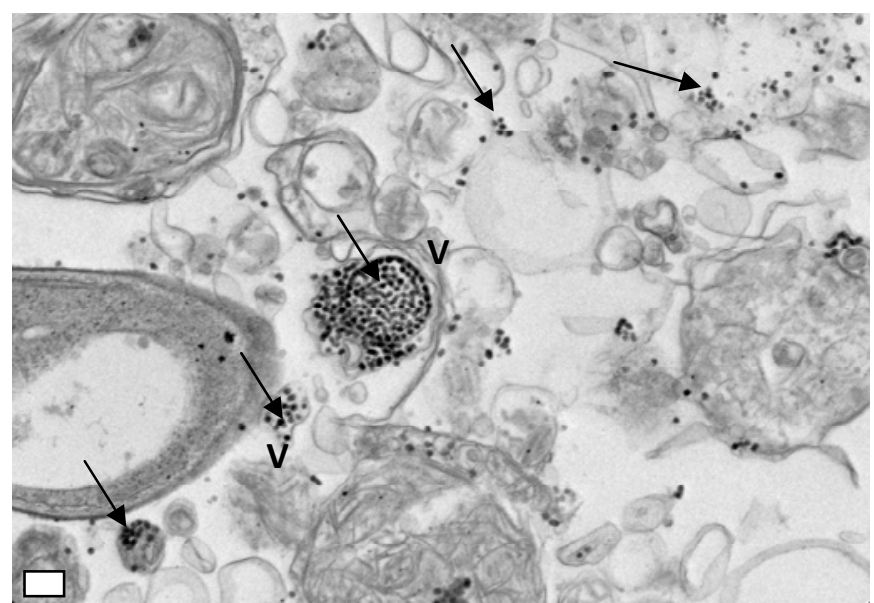

(f) 
Fig. 4. Advanced stage of brown muscle disease in $R$. philippinarum muscle observed under TEM. (a) Virus-like particles (arrows) in paracrystalline arrays (arrowheads) or free (arrows) among cellular debris (scale bar, $500 \mathrm{~nm}$ ). (b) VLPs (arrows) within a vesicle (V). This allowed to distinguish their icosahedral structure (scale bar, $100 \mathrm{~nm}$ ). 
Fig. 4.

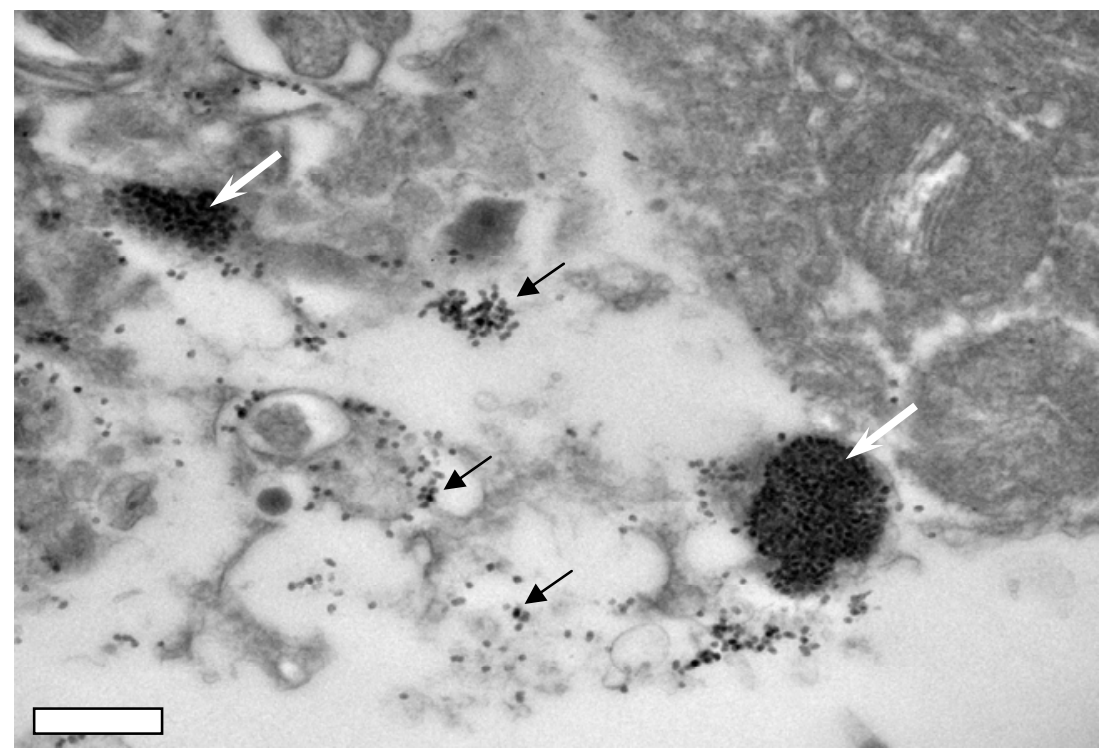

(a)

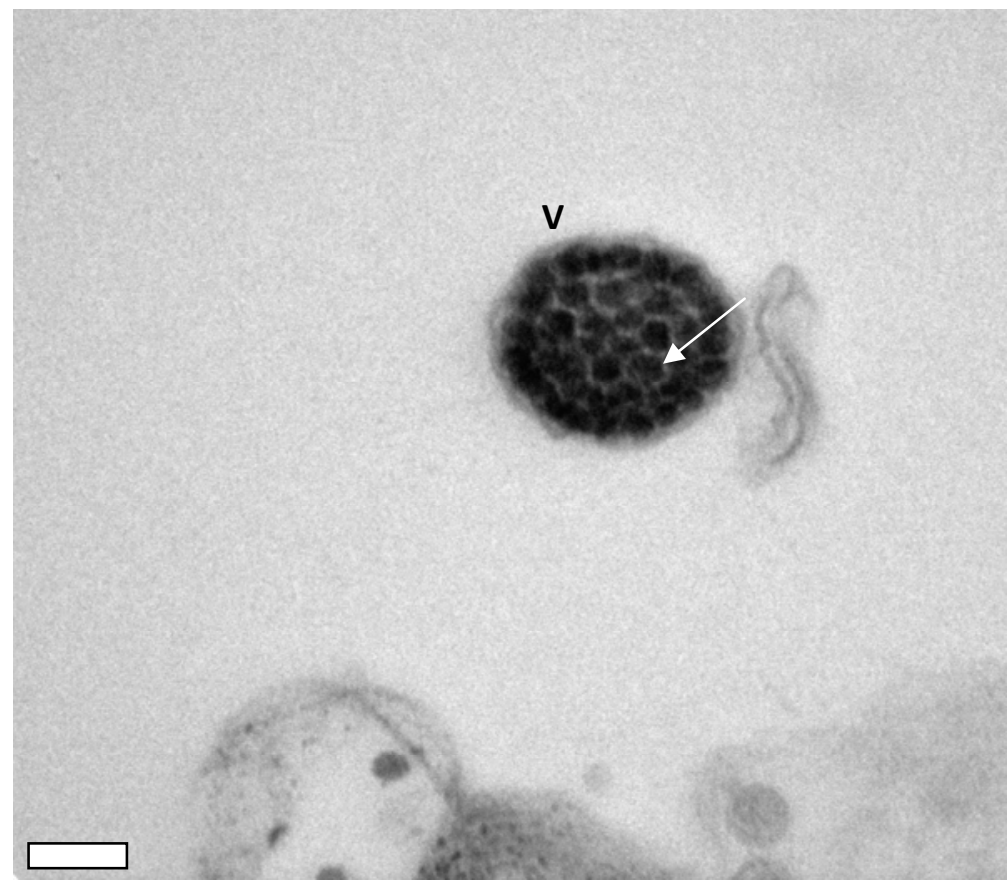

(b) 